\title{
(-9)
}

\section{China Pak Economic Corridor (CPEC): Facts and Fantasies}

\author{
Bushra Hamid $^{a}$, Shakeel Khan ${ }^{\text {b }}$ \\ a Institute of Management Studies, University of Peshawar, Pakistan \\ Email: dean_mis@uop.edu.pk \\ ${ }^{\mathrm{b}}$ Institute of Management Studies, University of Peshawar, Pakistan \\ Email: shakeel@uop.edu.pk
}

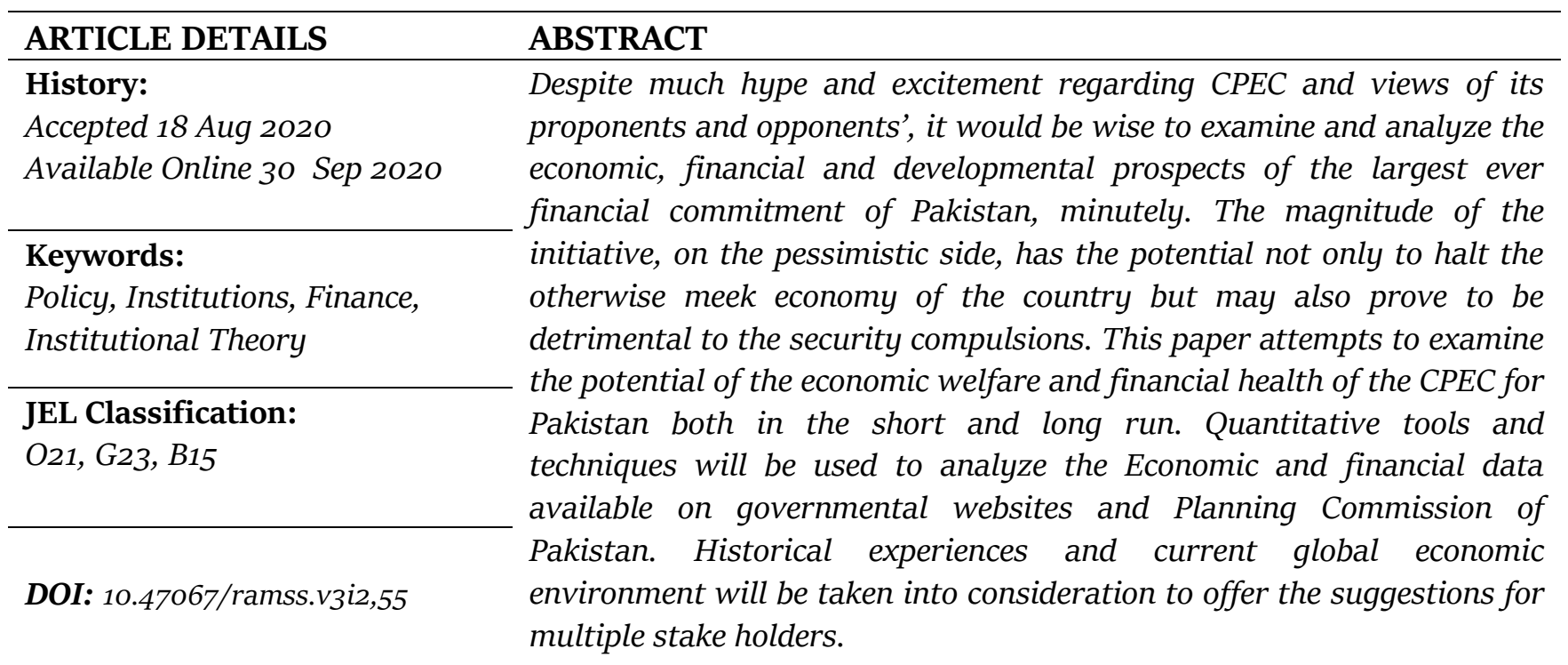

(C) 2020 The authors. Published by SPCRD Global Publishing. This is an open access article under the Creative Commons Attribution-

NonCommercial 4.0

Corresponding author's email address: dean_mis@uop.edu.pk

\section{Introduction}

CPEC (China Pak Economic Corridor) is part of the Chinese long term policy of OBOR (One Belt One Road). It consists of six such corridors with the stated objective of connecting South Asia, South East Asia, Eurasia and Africa through various infrastructure and energy projects. It has two components: 1) land route and 2) Oceangoing is correspondingly titled as "Silk Road Economic Belt", plus "21st century Maritime Silk Road" (Rahman \& Shurong, 2018). CPEC now is a $\$ 62$ billion project planned to be completed in 2030. Essentially the project connects the Xinjiang province of Western China to the Gwader Port in Pakistan via communication and energy infrastructure covering approximately 3000 kilometers. OBOR, covers more than 60 countries, $62 \%$ of the world population and 30\% of economic output with an approximately \$ 5 trillion in expenditures (Huang, 2017). 
Since CPEC passed through only one country; Pakistan, it is considered as the shortest and efficient corridor with the potential of integrating many regional economies (Nazir, 2016). Despite that CPEC is a Chinese project, however, Pakistan benefits from it by virtue of its geographical location (Ebrahim, 2017). It is estimated that the project has a potential of creating 700,000 to 800,000 jobs till 2030 (Nazir, 2016). Analytical evidence suggests that CPEC is equally and critically significant for Pakistan and China. Pakistan is in desperate need of finances to address the major issues of energy, debt provision, economic and budgetary gaps and development. On the contrary, China needs the assess and control of Gwader Port for its critical energy supplies from Middle East. Besides increasing global presence and influence (Ramay and Shakeel).

The world's most important checkpoint with daily oil flow of about 17 million bbl/d in 2011, roughly $35 \%$ of all seaborne traded oil and almost $20 \%$ of oil traded worldwide; Strait of Hormuz is located between Oman and Iran. Any obstruction to this checkpoint, even briefly may lead to significant raise in total energy cost. As more than $85 \%$ of crude oil exports transfers to Asian markets, with Japan, India, South Korea, and China representing the largest destinations through this checkpoint alone. (Eia, 2012). According to the Pentagon report, China imports at least $51 \%$ of its oil from the Middle East. Approximately $43 \%$ of this oil has to pass through the Strait of Hormuz while $82 \%$ of all Chinese maritime oil imports must pass through the Strait of Malacca.

Nevertheless, the critics and opponents of CPEC also have some valid reasons for apprehensions regarding the project. The alarming factors pointed out in this regard is that 1) Pakistan has not negotiated the project optimally, 2) have not prepared even an initial feasibility study of the project, 3) not organized and institutionalized it properly including the border and customs issues at Kashgar to Gwadar, 4) environmental impact as required by the law is not assessed (Pakistan Times, 2017).

Given the preceding, the objective of the paper is to:

- $\quad$ Assess the financial prospects of CPEC for Pakistan

- $\quad$ Examine the short and long term benefits of the project

- Underscore the security requirements for the project

- $\quad$ Offer suggestions and conclusions in the light of ground realities and institutional theory

\section{Financial Prospects of CPEC}

The reported information on CPEC suggests that Chinese funding for the project makes provision for approximated two third towards power and energy related projects, whereas one is envisioned for infrastructure projects. Soft loans for the infrastructure will be available at the interest rate of $1.6 \%$ as compared to similar loans by other institutions like World Band at the rate of $3.8 \%$ or more.

For investment in Power sector, the energy projects under CPEC will not be constructed or operated by either of the governments. For this purpose, the private investors will be provided loans by the Chinese Exim bank, established for this specific purpose for Independent Power Producers (IPP) only. The Exim Bank of China will finance these private investments at 5-6\% interest rates, while the government of Pakistan will be ensuring to purchase electricity at pre-negotiated rates. The rate of return of approximately $17 \%$ will be guaranteed by Pakistan through its institutional arrangement (Musings, 2017). 
Hussain (2017), has approximated a broad estimate of additional burden on Pakistan's external payment capacity regarding CPEC. According to him, there will not be any future liabilities for Pakistan in terms of balance of payments. In terms of material and services, the project cost will contribute an aggregate FDI by more than $\$ 1 \mathrm{bn}$ annually. Besides, inflows and local spending in infrastructure projects will add another \$ 4billion over 15 years. Nevertheless, the 17pc guaranteed return on these projects would cost annual payments of $\$ 2.4 \mathrm{bn}$ from the current account.

The infrastructure financing loans at 1.6\% interest to paid in 20-25 years will cost \$ 910 million annually, summarizing it to be less than 3.5bn annually. This amounts to $7 \%$ of foreign exchange earnings of the country as of 2016. Moreover, this does not take any incremental gains in and from GDP growth due to investment in energy and infrastructure. The loan amounts to be disbursed in 15 years, the tapered schedule will amount $\$ 2-3 b n$ being disbursed in initial years and less in the later years (Hussain, 2017).

The terms and conditions presented above are conducive, given the political risk and economic risks specific to Pakistan besides the security issues. Under such circumstances Pakistan cannot generate sufficient funds to realize its need for power and infrastructure provision without CPEC or similar investment and loan availability. Therefore, presuming that CPEC is a bad for Pakistan is incorrect as far as financial aspects are concerned.

\section{Short and long term benefits of the project}

Pakistan faces a dire shortage in provision of power to domestic as well as industrial demand, which is an obstacle not only to consumer anxiety but also industrial production. The alternate modes to overcome these shortages are much expensive but also inefficient. The statistics regarding the demand and supply of power generation in Pakistan figures an energy generating capacity is 24,830 MW with a shortfall of over of over 4,50oMW on a regular basis. This compels to load shedding of power nationwide for up to 5 hours daily. The situation further is responsible for 2-2.5 percent of decrease in annual GDP. As part of the "Early Harvest" scheme of the CPEC, an estimated 10,400 MW of additional generation of electricity is scheduled by March 2018 (Mughal, 2017).

Moreover, liquefied natural gas power (LNG) projects will be built to a to build a $\$ 2.5$ billion $711^{-}$ kilometer-long liquid natural gas pipeline from Gwadar to Nawabshah, which is a part of 2,775kilometre-long Iran-Pakistan gas pipeline, with the 80 kilometer portion between Gwadar and the Iranian border. Iran has already completed a 90o-kilometer-long portion of the pipeline on its side of the border (Mughal, 2017).

Economic Survey of Pakistan depicted that the industrial sector has recorded a significant growth of 6.8 percent compared to 3.62 percent increase in 2014-15, highest ever in the last eight years (Nazir, 2016). Since it offers the cheap labor, shortest route and a comprehensive infrastructure; has the potential to attract new investors in the region.

Since the CPEC route encompasses all the four provinces, it has the potential to develop the remote and poor areas of Baluchistan, Gilgit and Baltistan not only in terms of infrastructure but also to boost the products of these areas like fruits and minerals. Also, due to presence of 14 world's highest mountain peaks including K-2, it offers great promise in tourism sector of the country. Apart from that the promotion of socioeconomic development has immense promise of bringing peace and stability, specifically in Baluchistan. This will also reduce the pain of the province for being neglected for too long a time. All these factors can attribute to the efficient and effective writ of the State in the province 
through institutions and organizations.

The geostrategic location of being positioned at the center of oil rich Middle East and land locked Central Asia. Regarding the critical importance of China for Straits of Hurmuz and Malacca and troubled situation at home, Pakistan has the potential to play the central hub of trade in the region, integrate the other countries and make the Gwader port as the gateway to South Asia, Central Asia and China providing the shortest routes to the region. Hence exploiting the bilateral agreement to become a multilateral project by integrating the regional countries. Besides, the interdependency of the regional states through CPEC will create a direct stake in the others' stability.

\section{Security Requirements for the Project}

CPEC is not free of challenges specifically related to security concerns. It faces both internal and external challenges. Internally, Pakistan is facing political as well as security challenges, which can create obstacle in the implementation of the project.

\section{External Challenges:}

It is observed by many that India tends to resist any kind of benefit that Pakistan can have, may it be security concern or otherwise. Indian Prime Minister urged China to abandon the project and regularly protested against it and termed it as "unacceptable" (Express Tribune. January 07, 2016) Besides, Indians are concerned that involvement of Chines firms' in Gilgit-Baltistan will tantamount to stipulate legitimacy to the occupied part of Kashmir (Lim, May 16, 2016). Moreover, India reflects that Chinese people working on the project belong to the People's Republican Army, hence a threat to India's security (Chansoria, 2017).

Furthermore, India transmits that CPEC, through operational control over Gwador port would increase Pakistan's leverage and reinforce Chinese influence in the region (Bhattacharjee, May 12, 2015). Additionally, there is a possibility that Gwador port will eventually become a Chinese naval base. Besides Chinese encirclement of India by "Strings of Pearls" through China's through its involvement in a series of strategic naval ports in the region, in Sri Lanka, Myanmar, and Bangladesh being developed by China (Chowdhury, 2013).

On the contrary, after the arrest of Kulbhushan Yadav, an Indian naval officer serving at India's intelligence agency, in March 2016 and confessions of many dissidents of the banned terrorist organizations in Pakistan have reinforced the Pakistan's narrative of India spying and funding terrorist in Pakistan to Sabotage the CPEC project and acting as a spoiler in the region (Lim, 2016).

Beside India, the ever slow process of reconciliation in Afghanistan poses yet another challenge to the project. The consequential effects of tenacious instability in Afghanistan could subvert the security environment in both Pakistan and China (Ali, 2016). Pakistan accuses India's RAW and Afghanistan's National Directorate of Security (NDS) for creating disruptions and instability in Pakistan. Moreover, Uighur militants from the Xinjiang province pose a significant threat to Chinese interest in Pakistan (Ritzinger, 2015). The severity of the situation can be gauged by the Chinese decision to play a greater political and security role despite China's declared policy of non-interference in another state's matters (Esteban, 2016).

Despite its initial apprehensions about Gwador port and subsequent agreement with India and Afghanistan to expand Chabahar port as response to CPEC (The Dawn News, 2016). Iran has shown its desire to be part of CPEC, (Abbas, 2016). However, it is believed that Saudi-Iranian hostility could 
impede the improvement in Pakistan-Iran relations.

United States against all the perceptions did not oppose the CPEC. However, US consider CPEC as a long-term risk. In order to counter the Chinese expansion in the region there is a likelihood that US may advance its own New Silk Road Initiative to connect Central Asia to South Asia (Zimmerman, 2015) The US strategic ties with India through The Civilian Nuclear Agreement aimed to counter the Chinese influence in the Indian Ocean and maintain its dominant position in the region (Hussain, 2016; Javaid \& Javaid, 2016). However, US needs Chinese support in Afghanistan to counter the Russian threat (Zimmerman, 2015).

\section{Domestic Challenges}

Pakistan being a plural society is exposed to myriad security threats. The deficient political consensus and degrading internal security are the two main challenges towards the timely implementation of CPEC projects. The major sources are militancy, radicalization, insurgency, and sectarianism. Given the literature on the subject, Pakistan government itself is to be blamed for its failure to prevent these issues which are basically religion, water and economic based atrocities against the populace. Moreover, security threats tend to increase when political system become dysfunctional.

In the current scenario, Gwador port along with most of the major projects are located in Baluchistan. Besides, the province has its genuine grievances of being ignored for more than six decades, which made certain elements to demand autonomy and cessation. Therefore, given the fragile situation in Baluchistan, it is always on the priority of hit list by the insurgents.

A closer look at the map of the CPEC route depicts that the entire track is home to miscreants and opponents of the mega project. Besides, external elements collaborating with internal populace to plot against the project. Despite all the claims of successful operation in various tribal areas and urban locations, the bottom-line issue remains the same pointing towards the two key issues that need to be addressed not only for national security reasons but also to make CPEC a success story.

\section{Suggestions and Conclusions}

CPEC can be titled as the "Opportunity of the Century" for Pakistan, probably to a certain extent to China as well. The unprecedented funding and investment committed to this project have all the potential to ease off many pains and problems of the country, specifically associated with socioeconomic development. This is however, subject to effective and efficient implementation of the same. It has been observed that the two internal issues associated with the implementation process is the security and political instability. External issues are closely linked to the internal problems of the country. It is highly deplorable that Pakistan did not do its proper homework to explore and utilize the economic and developmental potential of CPEC. The mandatory requirement for any project of this magnitude is to first develop an institutional framework for the conduct of requisite activities. This framework provides for a system of feedback and feed-in to make the processes more effective and efficient. Therefore, without having a proper institutional infrastructure in place, the fruits of CPEC may never materialized

This is clear from the text that CPEC is financially a viable project with much promise to overcome the current issues of power, energy and infrastructure in the country. The gains from the project are multifaceted. On the internal front it will address the current economic issues with the potential of generating more resources and development of the human capacity. On the external side, it provides the opportunity of linking more than 30\% of the world output. Moreover, the trade and business opportunities will be significant to improve the unemployment and growth in GDP. It will 
reduce the burden of external sector and balance of payments.

To reap the benefits of the road infrastructure at maximum, the three fundamental requirements are to have relevant human capital, local connectivity and a favorable business environment to attract foreign direct investment (FDI). However, Pakistan portrays a dismal situation in all these areas; mainly attributed to poor institutional indicators, political instability and fragile legal system. The data presented by Mehtab Haider, in his article "Chinese experts point out risks, challenges for CPEC”, ranks Pakistan for political stability and absence of violence or terrorism, control-ofcorruption indicators. The situation is similar for rule of law and regulatory quality indicators.

In order to improve the current situation of deficient institutional infrastructure, it is suggested to first and foremost, to ensure more transparency. Other steps suggested are to device mechanisms towards economic dispute settlement, industrialization and proper implementation structure to ensure creativity and innovation. Unlike China, Pakistan did not establish any specific bank to facilitate the financing activities of CPEC. It is highly suggested to create various organizations, financial instruments like equity funds, Insurance cover ensuring skill development and extending connectivity to all regions including, Afghanistan, Central Asia and even to India through Wagah border.

On the security side, it is said that peace brings development. Pakistan has to ensure to address its internal security concerns with the help of various security mechanisms. As far as external security is concerned, the beauty of the project is that the investors, mostly from China will be more concerned to safeguard their respective investments, therefore, China will make sure to protect its national interest and will certainly be devising relevant mechanisms.

In a nutshell it can be concluded that CPEC to Pakistan is like a basket of eggs offered by China at some cost, however, it depends upon us the Pakistan that how we plan and intend to hatch the chicks.

\section{References}

Abbas, Sammer Syed (2016). Iran wants to be part of CPEC. Retrieved on January 1, 2018, From: https://www.dawn.com/news/1285404

Ali, Akber (2016). "China Pakistan Economic Corridor: Prospects and challenges for regional integration.” Arts and Social Sciences Journal 7, no. 204, P:1-5. doi: 10.4172/2151-6200.1000204

Bhattacharjee, Dhrubajyoti (2015) “China Pakistan Economic Corridor (CPEC)," Indian Council of World Affairs (Issue Brief). Retrieved on January 1, http://www.icwa.in/pdfs/IB/2014/CPECIB12052015.pdf

Bhattacharjee, (2015). China Pakistan Economic Corridor (CPEC) 11; Daniel Twining, As the U.S. pivots away, China bets on Pakistan. Center for Strategic \& International Studies. Retrieved on January 1,2018, From: www.csis.org/analysis/pacnet-26- us-pivots-away-china-bets-pakistan

Bender, Jeremy \& Rosen, Armin (2015). "Business Insider" Retrieved on January 1,2018, From: http://www.businessinsider.com/this-map-shows-chinas-global-energy-ties-2015-5

Chansoria, Monika date? China makes its presence felt in Pak Occupied Kashmir. Sunday Guardian. Retrieved on January 01, 2018. From: http://www.sun day-guardian.com/analysis/china-makesits-presence-felt-in-pakoccupied-kashmir

Chowdhury Roy Debasish (2013) Pakistan happy to aid in China's quest for land route to the west; India, not so much. South China Morning Post, Retrieved on January 1, 2018 From: http://www.scmp.com/business/commodities/article/1359761/pakistan-happy-aid-chinasquest-land-route-west-india-not-so 
Dawn News, (2016). CPEC: Iran, India, Afghanistan sign transit accord on Chabahar Port, Retrieved on January 1, 2018, From: http://www.dawn.com/news/1260176

Ebrahim T. Zofeen, (2017). The wire. Is CPEC good, bad or a disaster for Pakistan's economy and environment?. Retrieved on January 1 2018, From: https://thewire.in/151189/is-cpec-good-bador-a-disaster-for-pakistan-economy-environment/

EIA (2012). Strait of Hormuz is chokepoint for $20 \%$ of world's oil. US Energy InformationAdministration. Retrieved from: https://www.eia.gov/todayinenergy/detail.php?id=7830

Esteban, Mario (2016). The China-Pakistan corridor: A transit, economic or development corridor? Elcano Royal Institute, ARI 53/2016, p:1-9. Retrieved on January 1, 2018, From:http://www.realinstitutoelcano.org/wps/portal/rielcano_en/contenido?WCM_GLOBAL_C ONTEXT=/elcano/elcano_in/zonas_in/ari53-2016-esteban-china-pakistan-corridor-transiteconomic-development

Express Tribune (2016). "Chinese pressure sees Pakistan mull constitutional status of Gilgit-Baltistan”. Retrieved on January 1, 2018, https://tribune.com.pk/story/1023523/chinese-pressure-seespakistan-mull-constitutional-status-of-gilgit-baltistan/

Haider, Mehtab (2016). Chinese experts point out risks, challenges for CPEC. The News International Huang, Zheping (2017). Your guide to understanding OBOR, China's new Silk Road plan. Quartz Media. Retrieved on January 1, 2018, From: https://qz.com/98346o/obor-an-extremely-simple-guideto-understanding-chinas-one-belt-one-road-forum-for-its-new-silk-road/

Hussain, Ishrat (2017). Financing burden of CPEC. The Dawn News. Retrieved on January 1, 2018, From: https://www.dawn.com/news/1313992

Hussain, Jamal (2016). China Pakistan Economic Corridor. Defense Journal 19, no.6: P,13-21. Retrieved on January 1, 2018,From: http://search.proquest.com.libproxy.nps.edu/docview/1768622920/fulltextPDF/E9CD1Fo78705 44A1PQ/1?accountid=12702]

Lim, Cheng-hin Alvin (2016). The China-Pakistan Economic Corridor one year on-analysis: Eurasia Review Retrieved on January 1, 2018, From: https://defence.pk/pdf/threads/the-china-pakistaneconomic-corridor-one-year-on-analysis-eurasiareview.431537/

Musings, Haq (2017). CPEC Financing: Is Pakistan being ripped off by China?

Retrieved on January 1, 2018, From: http://www.riazhaq.com/2017/o7/cpec-financing-is-pakistanbeing-ripped.html

Mughal, Ahmed Rashid (2017). CPEC-An economic revolution for Pakistan. Pakistan Observer.

Retrieved on January 1, 2018), From: https://pakobserver.net/cpec-economic-revolution-pakistan/

Nazir, Mariam (2016). Analysis of determinants for CPEC's success and failure: Emerging challenges and lessons. Retrieved on January 1, 2018, from http://www.ipripak.org/wpcontent/uploads/2017/10/art3mnj21.pdf

Nazir, Maryam (2016). Macro and micro dividends of CPEC. Islamabad Policy Research Institute. Retrieved on January 1, 2018), From: http://www.ipripak.org/macro-and-micro-dividends-ofcpec-efforts-of-regional-and- international-players-to-disrupt-the-development-in-the-regionits-ramifications-and-rectifications

Pakistan Today (2017). Pakistan was not properly prepared for CPEC. Retrieved on January 1, 2018, from: https://www.pakistantoday.com.pk/2017/11/16/pakistan-was-not-properly-prepared-forcpec/]

Rahman, Saif Ur \& Shurong, Zhao. Analysis of Chinese economic and national security interests in China-Pakistan Economic Corridor (CPEC) under the framework of One Belt One Road (OBOR) Initiative. Retrieved on January from https://webcache.googleusercontent.com/search?q=cache:iL- 
HYfpHfQMJ:https://www.omicsonline.org/open-access/analysis-of-chinese-economic-andnational-security-interests-in-chinapakistan-economic-corridor-cpec-under-the-framework-ofone-be-2151-6200-1000284.pdf $+\& c d=2 \& h l=e n \& c t=c l n k \& g l=p k \& c l i e n t=$ safari $]$

Ramay, Ahmad Shakeel. A Chinese dream being materialized through Pakistan. SDPI. Policy Brief. Retrieved on January 1,2018, from: https://sdpi.org/publications/files/China-PakistanEconomic-Corridor-(Shakeel-Ahmad-Ramay).pdf

Ritzinger, Louis (2015). “The China-Pakistan Economic Corridor: Regional dynamics and China's geopolitical ambitions". National Bureau of Asian Research. Retrieved on January 1 2018, from http://www.nbr.org/downloads/pdfs/psa/Commentary_Ritzinger_o80515.pdf

Javaid, Umbreen \& Javaid, Rameesha (2016). Strengthening geo-strategic bond of Pakistan and China through geo-economic configuration. Pakistan Economic and Social Review 54, no. 1:p:123-142. Retrieved on January 1, 2018, from http://pu.edu.pk/images/journal/pesr/PDFFILES/9_V54_1_SUM2016.pdf

US Energy Information Administration, (2012). Retrieved on January 1, 2018, from https://www.eia.gov/todayinenergy/detail.php?id=7830

Zimmerman, Thomas (2015). The New Silk Roads: China, the U.S. and the future of Central Asia. Center on international Cooperation. New York University. Retrieved on January 1, 2018, From: http://cic.nyu.edu/sites/default/files/zimmerman_new_silk_road_final_2.pdf 